\title{
Building bridges and strengthening positions: Exploring the identity construction of immigrant bilingual teachers
}

Helena Colliander

The self-archived postprint version of this journal article is available at Linköping University Institutional Repository (DiVA):

http:/ / urn.kb.se/ resolve?urn=urn:nbn:se:liu:diva- 144866

N.B.: When citing this work, cite the original publication.

This is an electronic version of an article published in:

Colliander, H., (2017), Building bridges and strengthening positions: Exploring the identity

construction of immigrant bilingual teachers, International J ournal of Bilingual Education and Bilingualism. https:// doi.org/ 10.1080/ 13670050.2017.1400516

Original publication available at:

https:/ / doi.org/ 10.1080/ 13670050.2017.1400516

Copyright: Taylor \& Francis (Routledge) (SSH Titles)

http:// www.routledge.com/ 


\title{
Building bridges and strengthening positions: Exploring the identity construction of immigrant bilingual teachers
}

\begin{abstract}
This study explores how bilingual teachers with an immigrant background construct professional identity in the context of initial literacy and second language teaching of adults. Specifically, the study seeks to understand what the teachers' membership of different workrelated communities means for their professional identity and what capital the teachers use, negotiate and acquire to strengthen their positions in this professional field. The study is based on interviews with seven bilingual teachers. The data has been analysed from the perspective of situated learning theory and by employing some complementing concepts of Bourdieu used as thinking tools. The findings illustrate how the teachers construct their professional identity in relation to their students and by positioning themselves in different teacher communities. Moreover, the findings stress how the local school community plays a crucial part in determining the position the teachers obtain in the field. But in spite of being acknowledged as professionals, the teachers still need to negotiate their position by acquiring new capital and stressing the capital they already have.
\end{abstract}

Keywords: Bilingual teachers; professional identity construction; bilingual education; mother tongue education; Literacy Education and Second Language Learning for Adults (LESLLA)

\section{Introduction}

The world today is characterised by globalisation and migration and, as a consequence, the sector of second language teaching of adults has expanded. Research has revealed the advantages of bilingual education where two (or more) languages are used to encourage equity and diversity (Garcia, 2009) and/or support learning (Martin-Jones, 2017). Together with explicit instruction, the use of a multilingual repertoire by students and teachers has been identified as an effective way to prevent academic underachievement (Cummins, 2015; Thomas and Collier, 1997) and even though these findings are based on research on children, bilingual education is advocated for the education of adults too. It is seen to encourage metalinguistic awareness and creative thinking, and to facilitate human interactions. Moreover, it has more correlations with socio-economic benefits than monolingual education (Garcia, 2009). Yet, in many contexts, also within education for immigrants, a monolingual norm prevails. A language is a social construction which is tightly linked to the idea of a nation state. Monolingualism is regarded as something natural, desirable and efficient for creating unity within a country (Ibid.). As a result, the possibility of using the students' native language as a tool for second language acquisition is not always recognised.

This study focuses on the identity of teachers with an immigrant background, who teach with the students' mother tongue as a tool in the field of Literacy Education and Second Language for Adults (LESLLA) in Sweden. In this study, I will refer to them as bilingual teachers.

\section{Immigrant bilingual teacher identity}

A particular field of research focuses on the identity of native and non-native-speaking teachers (Ghanem, 2015). Holliday (2006), for example, stresses the hegemony of a language. He applies the notion of native speakerism to reflect the distinction between the 'native speaker' and the 'non-native speaker' in English language teaching and learning. The 'native speaker teacher' of English is seen to represent the Western culture in terms of both how s/he uses the language and how s/he teaches it. The 'non-native speaker', on the other hand, is described negatively, as someone with a deficiency in teaching or learning ability. Another study shows how being a native speaker or a non-native speaker influences how teachers of a foreign 
language come to construct their teacher identity: Whereas the 'native speaker teachers' were confident in teaching culture as part of the subject, the 'non-native speaker teachers' felt that it was not legitimate for them to do so (Ghanem, 2015). Even bilingual immigrant teachers, who teach other subjects than a foreign language, are seen to have experienced alienation at work. An interview study reveals that, alongside positive experiences, there were situations when, due to their immigrant status, they felt they had been rejected or that they did not count (Rubenstein Reich and Jönsson, 2006).

The language hegemony may also influence the employment conditions (Holliday, 2006). A study of teachers employed to use immigrant students' mother tongue as a tool for learning, shows that they did not experience a sense of belonging to their school communities. This was, for example, because, with their, often, short-term contracts and part-time work in many different schools, they lacked access to the tightly-knit groups of established employees and because the mother tongue subject sessions were not integrated in the mainstream teaching (Valenta, 2009). Other scholars have shown how the mother tongue instruction of minority groups is physically and symbolically marginalised, that there is lack of adequate teaching material and that the teaching and learning are not related to the students' life (McCarty, Collins, and Hopson, 2011). Also, the mother tongue instruction in Sweden has a sub-ordinated position in relation to other school subjects, since it is not mandatory (Ganuza and Hedman, 2015).

A consequence of the disfavouring structures that both follow and contribute to the hegemony of a certain language is that bilingual teachers need to struggle to acquire professional legitimacy and for the legitimacy of their subject. Accounts from bilingual teachers echo that they feel they are not real teachers in the eyes of their colleagues, and a commonly held belief is that they lack formal education. As a response, teachers seek to distance themselves from their bilingual identities by seeking access to teaching jobs with higher status (Valenta, 2009) or by pursuing more education than their employers think is needed. Yet others negotiate their positions by stressing the education they received in their native country (Ganuza and Hedman, 2015). Moreover, bilingual teachers who teach other subjects than the dominant language, have been shown to legitimate themselves by stressing their particularity in regard to their native-speaking colleagues, emphasising this as important for the students with an immigrant background. By this they believed that, for example, they could understand these students' alienation and act as a role model for them. They thought that it was easier for the students to understand them than the native teachers. In this sense, the teachers used their immigrant background when constructing their professional identity, viewing it as a resource (Rubenstein Reich Jönsson, 2006). But in regard to the native Swedish-speaking colleagues and students their bilingual background could also be viewed as stigmatizing and marginalising (Ibid.).

\section{Aim and research questions}

There has been little research on bilingual teachers' perspectives and ambitions in relation to their structural positions (Valenta, 2009), and this study sets out to reduce this gap. Given that bilingual teachers are structurally disfavoured even though they, not least in a LESLLA context, have an important role to play in students' learning, it is vital to develop knowledge of their profession. More specifically, the aim of this study is to explore the construction of professional identities of bilingual immigrant teachers in the field of LESLLA teaching. To do so, the following questions are central:

- What does the teachers' membership in different work-related communities mean for their professional identity? 
- What type of capital do the teachers use, negotiate and acquire to strengthen their positions in the professional field of initial literacy and second language teaching of adults?

\section{Identity, community of practice, and field}

This study combines situated learning theory with Bourdieu's notions of field, capital and dispositions (see e.g., Lave and Wenger, [1991]; Bourdieu, [1990, 1996,1998]). In situated learning theory, learning means identity formation, since the learning process involves the whole person. Little, by little, through participation in a social practice, the individual develops abilities and understandings. Essential for this process is to get the opportunity to participate in a community together with old-timers - more initiated members. The participation is built on situated negotiation and renegotiation of meaning (Lave and Wenger, 1991) on one's place in the community (Handley et al., 2006). Functions as well as tasks, activities and understanding are not isolated phenomena, but parts of a greater system of relations. Identity is likened to a trajectory towards a more central position and full participation in such a community of practice (CoP) (Lave and Wenger, 1991). Identity is also regarded as a journey through a whole landscape of practices, and there are different modes of identification in regard to different communities within it. A person can engage in a practice by doing things within it, s/he can imagine a membership in it, or align with its values and procedures. Especially when it comes to modes of imagination and alignment, one can identify with broader systems and not just with those one immediately engages in (Wenger-Trayner and Wenger-Trayner, 2015). Imagination, is something teachers can use to see themselves as part of a community of teachers in general and, likewise, they do not solely align to the local policies, but also to national regulations, like e.g. the curriculum.

Another model offering understanding of the concept of CoP distinguishes between two types of communities by referring to a tighter type and a wider type. The former is defined as a small and coherent entity (Hodkinson and Hodkinson, 2004a). In that way, the profession of a bilingual teacher in the LESLLA field contains many different communities. For example, there are the teachers' work team, and the teaching and learning practices made up by the teacher and the learners. Like any CoP, they are characterised by people engaging in a mutual enterprise, by certain actions and artefacts, e.g. experiences and routines (see Wenger [1998]). The wider type of community can be seen as an occupational and organisational context, which consists of many overlapping $\mathrm{CoP}$ at different levels and can be compared to what Bourdieu calls a field (Hodkinson and Hodkinson, 2004a). According to Bourdieu (1998), a field is like a market, or even a game, where groups of agents position themselves with their different species of capital - economic, social and cultural. All forms of capital constitute symbolic capital in the social communities where they are recognised and valued. Some forms of capital may be of particular interest for interpreting how bilingual teachers construct their professional identity. It is of significance to see both what capital is given value in the field of LESLLA teaching and what is misrecognized.

The cultural capital has been categorized into three states; institutionalised, embodied and objectified. Of interest for the study is the institutionalised state, to which formal academic qualifications can be referred. The embodied state too, provides an analytical lens. Embodied cultural capital is an integral part of the person, a habitus (Bourdieu, 1996), i.e. a system of dispositions that is fundamental for individual orientations, actions and thinking (Bourdieu, 1990). This implies a close connection to identity. Language is another example of embodied cultural capital. For example, the ability to adapt one's language to the norms of the language convention will influence how one perceives one's own social worth. In turn, this governs one's relation to different fields and positions in the social world (Bourdieu, 1991). 
The link between the field theory and situated learning, can, as previously stated, be understood in terms of a teacher belonging to several overlapping communities that constitute the occupational field of a LESLLA teacher.

Another link between the theoretical perspectives is the outlook on the relation between the individual and the world. Hodkinson and Hodkinson (2004b, 180) write that

learning involves the complex and often reflexive interrelationships between community of practice, individual dispositions to learning, inequalities of position and capital, and wider influences upon, and attributes of the field.

From their study, Hodkinson and Hodkinson confirm "that workplace learning cannot be understood through the abstraction of any one of these elements at the cost of excluding the rest" (180). Following their line, the wider occupational LESLLA teacher community is seen as a field, where the teachers' professional identity, due to their dispositions, forms of capital, and positions in the local communities, is negotiated.

\section{Context}

The teachers in this study worked in the system of Swedish for Immigrants (SFI). Within SFI, learners with limited educational background are offered study track 1, which includes the beginners' course A and the continuing course B. The goal of SFI is that the students should acquire basic knowledge and skills of Swedish. Learners who are not print literate are also offered courses in initial literacy. According to the SFI curriculum, reading and writing skills can also be developed in the students' mother tongue (The Swedish National Agency for Education, 2012). In fact, it is the only time the mother tongue is mentioned in this document. Yet, there are only some municipalities and schools which provide mother tongue-based instruction by the employment of mother tongue teachers or teacher assistants (The Swedish Schools Inspectorate, 2010:7).

The teachers in this study, however, taught with a students' mother tongue as a tool. Since they were either employed as SFI teachers or mother tongue teachers, I refer to them as bilingual teachers. This is to indicate that they used mother tongue teaching, that they might teach initial literacy in this particular language, and that they had an immigrant background themselves. Additionally, I use the concept of 'native speaker teacher' for their colleagues who only used Swedish as the language of instruction.

\section{Methods}

The data has been collected through semi-structured interviews. All interviews began with a part where the teachers were encouraged to tell their story about how they had become LESLLA teachers and developed in this profession. These stories were followed up by questions to clarify and deepen and/or broaden the answers. Then, questions about the teacher's current work and future professional plans were asked. By being an account of actions and episodes the teachers had experienced and interpreted, the stories provided rich qualitative data on how they understood themselves and their identity construction.

The participants in the study were seven bilingual teachers, who had moved to Sweden themselves, either as teenagers or young adults, and who were or had been full-time employed with LESLLA teaching in a folk high school ${ }^{1}$, a private SFI provider, or an SFI school run by the municipality. These schools all taught according to the national SFI curriculum, but they

\footnotetext{
${ }^{1}$ A type of civic education, run by NGOs or the county council.
} 
differed from most SFI schools in the sense that they offered mother tongue-based teaching. Two schools employed mother tongue teachers alongside SFI teachers. The third school had in in addition to 'native speaker SFI teachers', one SFI teacher who used his learners' mother tongue in teaching and, in addition to that, there was a team of bilingual teacher assistants to facilitate the students' learning. An overview of the teachers, four women and three men, is given in table 1.

Table 1 Background information of the teachers

\begin{tabular}{|c|c|c|c|c|}
\hline Name & $\begin{array}{l}\text { Mother } \\
\text { tongue } \\
\text { primarily } \\
\text { used in } \\
\text { teaching }\end{array}$ & Current position & $\begin{array}{l}\text { Educational background } \\
\text { before the LESLLA career }\end{array}$ & $\begin{array}{lr}\text { Previous } & \text { professional } \\
\text { experience } & \text { mentioned } \\
\text { in the data } & \end{array}$ \\
\hline Amela & Bosnian & SFI teacher ${ }^{\mathrm{a}}$ & $\begin{array}{l}\text { A teacher degree for the } \\
\text { Upper secondary school }\end{array}$ & $\begin{array}{l}\text { Working as a teacher in } \\
\text { secondary school. } \\
\text { Teaching a mother } \\
\text { tongue in junior school } \\
\text { Working in a } \\
\text { bookbindery }\end{array}$ \\
\hline Geedi & Somali & $\begin{array}{l}\text { Mother tongue teacher } \\
\text { Work team leader }\end{array}$ & $\begin{array}{l}\text { University courses in Social } \\
\text { Science }\end{array}$ & $\begin{array}{l}\text { Working as a mother } \\
\text { tongue teacher assistant. } \\
\text { Teaching a mother } \\
\text { tongue in primary school }\end{array}$ \\
\hline Mohammed & Arabic & $\begin{array}{l}\text { Mother tongue teacher } \\
+ \\
\text { Student coach }\end{array}$ & $\begin{array}{l}\text { University education in } \\
\text { Interpretation }\end{array}$ & $\begin{array}{l}\text { Working as an } \\
\text { economist. } \\
\text { Working as a teacher } \\
\text { assistant with immigrant } \\
\text { youth }\end{array}$ \\
\hline Omaima & Arabic & Mother tongue teacher & $\begin{array}{l}\text { English teacher in primary } \\
\text { school }\end{array}$ & $\begin{array}{l}\text { Teaching English as a } \\
\text { foreign language in } \\
\text { primary school }\end{array}$ \\
\hline Omed & Arabic & $\begin{array}{l}\text { SFI teacher } \\
\text { Work team leader }\end{array}$ & $\begin{array}{l}\text { University courses in } \\
\text { English Literature }\end{array}$ & $\begin{array}{l}\text { Working as an English } \\
\text { teacher. } \\
\text { Working as a teacher } \\
\text { assistant within other } \\
\text { levels of SFI }\end{array}$ \\
\hline Roya & $\begin{array}{l}\text { Pashto and } \\
\text { Dari }\end{array}$ & Mother tongue teacher & $\begin{array}{l}\text { Maths and Science Teacher - } \\
\text { degree for the primary } \\
\text { school }\end{array}$ & $\begin{array}{l}\text { Doing internship as a } \\
\text { child minder in } \\
\text { preschool. } \\
\text { Working as a teacher of } \\
\text { newly arrived immigrant } \\
\text { children in elementary } \\
\text { school. } \\
\text { Working as language } \\
\text { pedagogue in preschool }\end{array}$ \\
\hline Sazan & Arabic & SFI teacher & Master's in Chemistry & $\begin{array}{l}\text { Working as a teacher } \\
\text { assistant at university } \\
\text { Teaching Maths and } \\
\text { Science in Secondary } \\
\text { School } \\
\text { Working as a teacher in a } \\
\text { sewing project for } \\
\text { Romani women }\end{array}$ \\
\hline
\end{tabular}

a) This teacher did not currently work as a mother tongue teacher as the migration to Sweden from areas where Bosnian was spoken had decreased dramatically. 
The participants all gave their consent to participate. The data collected will be solely used for the purpose of research and the confidentially of the teachers is maintained by the use of pseudonyms instead of real names. Information which is not relevant to the research questions, but may contribute to the identification of the teachers has been modified to prevent the participants being identified.

Each interview was conducted in Swedish and lasted about an hour. They were audio recorded and later transcribed. The NVivo software 10.1.0 was used for analysing the data. The parts of the interview that targeted the professional teacher trajectory were coded. I applied a thematic analysis, focusing on the content and on finding themes on the basis of the research questions (see Braun and Clark [2006]). In an abductive process, I moved between the data and theoretical notions to see which notions could best inform the emerging themes. In the end, the research questions were slightly adjusted to the themes. Moreover, I used the data semantically as actual experiences, and latently, by analysing how they presented themselves through these experiences (see Braun and Clark [2006]). Essential for the analysis has been the understanding of the interviews as socially constructed in an interplay between the interviewer and the respondent (see Kvale and Brinkmann [2009]) and that the identity of both impacts the interview situation (see Vincent and Warren [2001]). For example, one teacher explicitly used my name when illustrating a 'native speaker teacher'. This example illustrates that my perceived identity as an ethnic Swede was something that was noticed and related to. In turn, this highlights that the bilingual teachers' identity is visible, not just in what they told about themselves, but also in how they did this.

The quotations used in the results section were translated into English. It was difficult to translate in a way that completely covered what was said, but the guiding principle was to be truthful to the meaning of the quotation rather than to its form. Thus, a standardised and written type of language was used.

\section{Findings}

In the first section I present how teachers constructed their professional identity in relation to the students. Then, I deal with how they constructed identity in regard to other work-related communities, whereas the third, final, section deals with how the particular local school community enabled the teachers to get a strong professional position.

\section{Constructing identity in relation to the students}

\section{Being an old-timer of the new Swedish-speaking and new citizen communities}

The teachers said that they worked contrastively, comparing the script, the grammar and the words of the mother tongue and the Swedish language. Also, they could explicitly explain the meaning of new words and phrases in the students' mother tongues. Some referred this to their own trajectory as a newcomer in the Swedish-speaking community. Mohammed said:

I try to facilitate by interpreting in Arabic, showing them [the students] how one uses Swedish in Arabic. Because that will be much easier. I mean, when I came here, 30 years ago, when I learned Swedish, it wasn't like that. One had to learn from a Swedish teacher and he talked Swedish, and one just had to keep up and understand as much as possible. Now, one can get it served in one's own language

The quote reflects how the teacher's understanding of himself as a teacher of Swedish was not just related to the formal work assignment and the learners' needs, but also to his own 
former experience of struggling with Swedish in an educational setting. In that sense, one can understand the immigrant bilingual teacher as someone who has come to master the new language in a trajectory resembling that of the learners. Both were speakers of a second language. Moreover, some teachers said that they explicitly shared their own experiences of language struggles with the students.

The teachers also presented themselves as people who facilitated the learners' trajectory into the new Swedish citizen society, a community, in which they had become initiated members. The ambitions to help the students to learn Swedish and achieve print literacy were related to the wish to facilitate the students' establishment as citizens in the Swedish society. For example, the teachers articulated that they wanted the students to gain greater selfconfidence and be able to stand on their own feet in everyday life. Also, the teachers spent much time outside the lessons supporting the students in personal and practical matters, e.g. by reading and translating private letters and giving advice.

The social part is also something to help them with everything that can influence their capacity to learn or the ability to stay in school and study instead of sitting with an SMS in their hand and thinking: "What's this? What's this?” If I quickly tell them what it is, they can relax from the beginning. So, that's also one of my important roles, that they will end up in a . . . state, where they can have peace in their mind and study. (Geedi)

As the quotation shows, this support was thought to improve the students' learning conditions. Even if it implied a heavier workload, the teachers said they were willing to give such support.

\section{Being someone who crosses boundaries and builds bridges}

Whereas the teachers shared membership with the students in the mother tongue and new Swedish-speaking and citizen communities, in parallel they participated in others, e.g. in a teacher community, together with 'native speaker teachers'. This double membership could sometimes be problematic. When talking about the workload that the membership in the student-shared community implied Sazan said:

According to my culture, if I say to a student: “No, I can't.” At once, they say: “Aha, she has become Swedish now". But then I explain to them that I have a family and I work here. "I've a group. I'm a teacher. I'm not here to sit and listen to all your problems. I'll help you as much I can after my lessons, not during the lessons.” I've stopped it during the breaks too.

The quotation demonstrates a scenario when a teacher is not living up to the expectations of the students. The students regarded her as someone who had crossed the boundaries of their cultural community. Sazan, however, did not imagine (see Wenger-Trayner and Wenger-Trayner [2015]) herself as a member in a "Swedish" community. The reason that she restricted her services to her students was that she aligned with the teacher community. Her identity as a teacher was more important than sharing a certain cultural behaviour with the students. Later on, in the interview, however, she acknowledged that she still needed her colleagues to say no to the students' request on her behalf. She felt that she could hardly do that herself without hurting or embarrassing the students. Consequently, the boundary crossing between different communities was not always without conflict for the bilingual teacher.

Even if the boundary crossing in some situations was problematic, the teachers' multiple memberships in student and teacher communities were, largely, highlighted as a resource. As 
was illustrated in the previous section, the bilingual teachers' double linguistic capital and knowledge of the society was used for supporting learning. Some used the attribute bridge builder to demonstrate how they could improve the relations between the students and the society they were establishing themselves in. Moreover, the bridge building was also about helping representatives of the Swedish society, e.g. 'native speaker teacher' colleagues, to understand the students. It could be about acting as an interpreter between a student or a colleague, or mediating in misunderstandings between them. These functions were possibly due to the bilingual teachers' embodied cultural capital, acquired through a trajectory in different communities in Sweden. They could, literally and figuratively, understand the students and the teachers because of their linguistic and multi-cultural competence.

\section{Constructing identity by positioning oneself in different teacher communities}

Apart from memberships in communities that the teachers engaged in, e.g. the teaching and learning communities, they also created their identity in regard to imagined teacher communities (see Wenger-Trayner and Wenger-Trayner [2015]). In this section, I will present three of these communities that were most salient in the data and elaborate on what they meant for the teachers' professional identity. However, these communities played different roles for different teachers. Even if all teachers imagined a membership in the community of LESLLA teachers, they did not all explicitly position themselves in the bilingual or the qualified teacher community, or they emphasised these two memberships less.

We, the LESLLA teachers

The teachers claimed that LESLLA teaching was different from other types of teaching. Mohammed, for example, said:

It requires lots of energy and much patience, and much repetition to make them understand what one actually means. It's different when one is with the well-educated. I use to teach the C-D students on Tuesdays, in the mother tongue and, there, one observes a great difference in the communication. One doesn't need to make that much effort to get the information across, but these A-courses, they're the foundation to everything and they're demanding, demanding, demanding.

The quotation reflects a distinction between the teaching conditions in the $\mathrm{C}$ and $\mathrm{D}$ courses, the higher level of SFI, and LESLLA. In spite of the similarities of teaching a second language to adults, the teacher highlighted the specific nature of LESLLA teaching. Both the teachers with experience of other SFI tracks and teachers with experience of other teaching contexts emphasised the differences. Like in the quotation above, the necessity of repetition was identified as a characteristic of LESLLA teaching. Moreover, the LESLLA teacher work was considered to be more demanding since more patience and engagement was required from the teacher to engage the students.

\section{We, the bilingual teachers}

Much of what the teachers saw as essentials in LESLLA teaching was linked to the possession of multi-linguistic and multi-cultural capital. Whether these essentials were about the ability to listen to the students' problems, understanding their learning needs and strategies or solving conflicts, it implied that the teachers spoke the language of the students and/or understood their way of thinking/feeling. The following quotation can be seen as an example: 
When you are occupied, and are talking to another person and a student comes and says to you: "Good morning”, you don't want to interrupt your conversation. They say once again: “Good morning, Helena”. You don't answer. Then they say: "Helena is not nice. She's very racialist. Did you know she was a racist? Twice, I said good morning to her, but she didn't answer." . . . Then, I tell them about the culture, that you wouldn't have shown respect for your colleague if you had interrupted the conversation. "It's a culture clash", I say. "You too, need to learn that when a teacher's occupied, you can't disturb her and say good morning." The students feel that it's embarrassing when the teacher doesn't answer them .... . They come and tell me everything that they experience in the classroom and, sometimes, it's difficult for me. At the beginning, I tried to explain how it was here, because I've had so many things during my 'journey' here in Sweden and with the job and everything. Then they became more hurt, so I said, "I go and talk with that teacher. I'm convinced $100 \%$ that she didn't mean what you experienced.” Then, I take the teacher aside and tell her everything. "Here there are some misunderstandings. Can we sit and talk about it and solve the problem?” (Sazan)

Here, Sazan presents herself as a conflict resolver, enabled through the embodied cultural capital she had acquired in trajectories into different communities in Sweden. She could understand the students and the teachers because of her linguistic competence and because she was familiar with the cultural behaviours in different communities. In this quotation, she accentuates the capital she had, in contrast to her 'native speaker colleague'.

Even if the teachers, in this sense, could position themselves in relation to the 'native speaker teachers', there was, simultaneously, the idea that these two groups, due to their different functions, compensated each other. The 'native speaker teachers' were seen to be able to better explain the structure behind Swedish and to speak grammatically correctly, whereas the bilingual teachers, as previously stated, could act as bridge builders and more easily communicate with the students. Nonetheless, there were also examples of how teachers negotiated the fact that they did not speak a standard variety of Swedish. One such example is seen in a statement uttered by Omaima when talking about her role as a home language teacher: "I'm a home language teacher. Maybe I have an accent, but I have planned everything". This quote illustrates how the way of speaking was to be balanced with her embodied cultural capital of being a capable teacher, something which in turn, in line with Bourdieu (1991), indicates that the teacher's social value was linked to the language conventions and had to be negotiated to position Omaima as a professional. Moreover, she compared herself with some 'native speaker teachers' as regards their attitudes to the students and where the other teachers fell short. In this way, she pointed out that one's way of speaking was not a guarantee of being a good teacher.

\section{We, the qualified teachers}

Another community the teachers identified with was that of the qualified teachers. Omed stressed his second language teacher education. Even though he was used to language teaching when he started to teach LESLLA learners, and even though he was given responsibility for his own classes before getting formal qualifications as an SFI teacher, he could see that acquiring adequate education for LESLLA teaching implied both institutionalised and embodied capital. Also, it helped him to position himself: "How many like me are there? With a teacher qualification and at the same time being multilingual - there are not many, I believe, at this level"

Successively, the teachers had strengthened their positions as qualified LESLLA teachers through the acquisition of additional institutionalised cultural capital. The reasons to study were 
to obtain basic qualifications, to acquire a teacher certificate valid in Sweden, and to learn more about initial literacy or second language teaching in particular and/or of teaching in general. Mainly, the teachers stated that they did it to develop professionally. But, the decision to pursue further education also implied that they could strengthen their position in the labour market. Some teachers told about the struggle to get a job or be acknowledged as a teacher before their LESLLA teaching career and Omed said about his choice to pursue a teacher degree: "It was the knowledge I wanted, the educational mainly, and then everything else - that it gives security, influences the salary and everything."

Through getting adequate education they could shift from being a mother tongue teacher or a teacher assistant position to employment as an SFI teacher. Three teachers had done so and two had tried. Roya said:

Sometimes, one sees or hears signals that those who are SFI teachers have a higher status than the ones who are mother tongue teachers. Because we mother tongue teachers are a little different. Not everyone has the same competence. . . So . . . people believe that we're not highly competent. But it's only the title . . . . If I get the SFI title I'll continue in the same way. I'll work as I do now.

Here, Roya points out the hierarchy of the SFI teachers and the mother tongue teachers, where the latter group, due to individual differences, are viewed as less competent even if both groups carry out more or less the same job. According to the quotation the teachers' positions as bilingual teachers implied that they were considered to lack institutionalised and embodied capital.

Apart from acquiring new institutionalised capital, the teachers stressed that they had gained embodied cultural capital, which showed them to be qualified teachers. Personal experience, gained through the path of life, was articulated to be more useful for LESLLA teaching than formal education. Moreover, the teachers used their thirst for learning to balance the lack of knowledge of LESLLA teaching they had at the beginning of their career. This was visible in how teachers said that they actively turned to more experienced colleagues, their students and/or books on relevant subjects to learn more about the teaching and learning conditions. In this sense, the teachers showed that, due to their individual dispositions, they could orient themselves in the new field.

\section{Constructing identity in regard to the local school community}

The communities that the teachers primarily engaged in (see Wenger-Trayner and WengerTrayner [2015]), e.g. the teaching and the learning communities and communities shared with colleagues, were all part of the overall local school community. In this section, I will first outline how membership in this community relates to the imagined teacher communities referred to in the previous section. Then I will show how the teachers came to acquire a strong position in this local community.

\section{Being part of the local school community enables membership of other communities}

The communities of the LESLLA teachers, the bilingual teachers and the qualified teachers were all moulded within the school community. The following quotation illustrates these relations:

I'm proud to work in this school because I feel it's unique. Many schools say: . . . "We've mother tongue teachers too . . . . I work as an SFI teacher, but then there's a translator 
with me". "You can't say that there's a mother tongue teacher with you. It's just a translator" .... The school has confidence in me as a mother tongue teacher to plan the lessons, the week, the term and, then, the SFI teacher comes and completes what I've done ... . In this [study] track, the role of the mother tongue teacher is greater than the role of the SFI teacher. The SFI teacher's role in the A-course is only to complete or work according to what I've planned as a mother tongue teacher. (Omaima)

Here, Omaima's identity as a bilingual teacher is in focus. She reveals that she gained access to the qualified teacher community. Although she was not an SFI teacher, the school acknowledged her as a competent teacher by giving her responsibility and autonomy. The access she gained to the community of qualified teachers was, furthermore, related to the specific conditions of LESLLA teaching. In this field, the bilingual teacher is said to have a particular function. Thus, it seems that the teachers' strong position in the school community gave them confidence when positioning themselves in the imagined professional communities.

\section{Becoming an initiated member in the local school community}

The teachers' strong position in their school community had many reasons. Overall, the teachers' social capital formed a foundation for their employment as LESLLA teachers. Most of them were known to someone who worked at the school, and they had been encouraged to apply for the position. In that sense, they were invited from the start to gain access to the mutual practice.

A crucial condition for the confidence the bilingual teacher had in their ability, was the positive attitudes the school had towards the use of the students' mother tongue in LESLLA teaching. These attitudes affected the work conditions in different ways: The teachers were employed on the basis of their bilingual capital and the education was organised in such a way that they had much freedom in teaching. There was cooperation between bilingual teachers and 'native speaker teachers', or alternatively, between the SFI teachers and multilingual teacher assistants. Additionally, some of the bilingual teachers held or had held a position as a work team leader.

The schools' values on mother tongue-based education as reflected by the teachers, can, moreover, be understood as a reproduction of the community's values. As newcomers, the teachers had the opportunity to learn from one or a few old-timers (see Lave and Wenger [1991]) among their colleagues. Generally, these old-timers seem to have been important for how the new teachers came to understand LESLLA teaching and learning and act as professionals. The new teachers had opportunities to observe the old-timers, to work with them, and/or, discuss teaching dilemmas with them. Some highlighted another bilingual teacher with longer experience of LESLLA teaching as the most important old-timer, but others stressed the impact of a native-speaking colleague. In any case, the mother tongue-based teaching was highly advocated and/or practiced by these significant old-timers.

The teachers' trajectory towards a strong position in the school community did, nonetheless, include negotiation. As, previously illustrated, the teachers had taken steps to acquire further institutionalised capital and, secure their position in that sense. Furthermore, there were also changes in the school communities, which implied better working conditions for the bilingual teachers. In one school, a system that prevented students to turn directly to their bilingual teacher in private matters was introduced. In another school, it was the nativespeaking colleagues who changed their behaviour towards how they used the bilingual teacher as an interpreter: 
Now, it's not as stressful as it was in the beginning. . . . It was the colleagues too. They took me from my lessons . . . . we brought it up, that: No, the colleagues are to have patience, to wait . . . to show me respect as a teacher, too. So, this has happened during the last years (Sazan)

\section{Discussion and implications}

This study sets out from the overall aim of exploring bilingual immigrant teachers' professional identity construction in the field of initial literacy and second language teaching of adults. The findings display the complexity of the teachers' identity construction and will be discussed here on the basis of the research questions.

\section{The significance of memberships in different communities}

The first research question concentrates on what the teacher's membership of different workrelated communities means for the professional identity. According to the results, the teacher's professional identity is constructed in relation to many of these communities. Firstly, there are the communities that the teacher actively engages in, such as the teaching and learning community and the general school community. Additionally, there are the communities that the teacher predominantly aligns with or imagines membership of, such as the LESLLA teacher, the bilingual teacher, and the qualified teacher communities (see Wenger-Trayner and WengerTrayner [2015]). The findings reflect that the communities in which the teacher engages, generally mean much for one's overall position in the field of LESLLA teaching. Previous research (e.g. Valenta, 2009) has shown that bilingual teachers, because of structural issues, often have a weak position in their school(s). This study, however, gives another picture. The data shows that there are bilingual teachers who, due to the school's way of organising the teaching and the values behind it, are granted full participation in the school communities. Moreover, the strong position one has in the local school community seems to positively influence one's positioning in the communities in which one imagines one has membership. Through this position, where one's professional capital is acknowledged, one gains a greater self-confidence. In that sense, the local community seems to be superior to the imagined communities when it comes to teacher's identity construction.

Secondly, it is possible to see how the membership of one community affects the teacher's relations to other communities. When the actions and values in a certain community greatly differ from those in other communities, the teacher's membership of another community implies a positioning in itself. This can be seen in how a teacher, by aligning him/herself with the overall teacher community, automatically distances him/herself from the cultural community shared by the students, and how this cause tensions both within the community and within the person (see Handley et al. [2006]). In other cases, the very peculiar nature of a community is that it differs from others. By identifying with the LESLLA teacher community and the bilingual teachers' community, the teacher positions him/herself against the other teachers of SFI, i.e. the 'native speaker teachers'. Moreover, the identification with the qualified teacher community implies a position taken against the unqualified teachers,

\section{Capital for strengthening one's position in the field}

The second question focuses on what type of capital the teacher uses, negotiates, and acquires to strengthen his/her position in the professional field of LESLLA teaching. It is striking how at least some of the teachers in the study, despite being acknowledged in their schools, still defended their position in LESLLA teaching. Consequently, a strong position in the field is, not 
completely granted by the access given in a local school community. Simultaneously, the position is also negotiated in relation to other agents of the field (see Bourdieu [1998]), especially the imagined community of 'native speaker teachers'. As Holliday (2006) points out, there is a difference in status between the 'native speaker teacher' and the 'non-native speaker teacher'. Like his study and others, e.g. Valenta' s [2009]), this study reflects such power relations. They are visble in how the bilingual teacher sometimes meets the assumption that s/he has few qualifications and s/he may experience a shortage of lingusitic capital. In turn, these are things which contribute to the teacher's identity construction since they question her/his professional legitimacy (see Bourdieu [1991]).

The bilingual teacher, however, is not passive, but struggles for a stronger position in the field. The findings support the results of other studies (Rubenstein Reich and Jönsson, 2006; Ganuza and Hedman, 2015), which have illustrated the strategy of stressing one's strengths in regard to native teacher colleagues to legitimate oneself in the Swedish school culture. It is essential for the bilingual teacher to highlight the capital s/he already has. The institutional cultural capital is particularly important. In line with Valenta (2009), the findings illustrate how the teacher, according to her/his individual dispositions, both acquires institutional capital and emphasises the formal qualifications s/he already has. This contradicts the conceptualization of the bilingual teacher as someone who lacks relevant education. Education appears as a way to get capital, recognised in the field (see Bourdieu, [1998]).

Apart from acquiring and stressing one's institutionalised capital, the teacher also legitimizes her/himself by stressing different types of embodied capital. As Rubenstein, Reich and Jönsson (2006) observe, the teacher's own background is considered as a resource when it comes to the teaching of other immigrants. The bilingual teacher's ability to more easily communicate with the learners, in comparison with native Swedish speaker teachers, is a reason why they were employed at SFI in the first place. In the LESLLA teaching community, the bilingual capital of the teachers is acknowledged, not just because the students are immigrants, but also since they have a low level of education. Because of that, the students are regarded to have a greater need of mother tongue tuition and possibly also additional support. Drawing on Bourdieu (1998) one can, thus, maintain that the teachers' multi-linguistic capital, as well as the embodied capital of their own immigrant experience and a multi-cultural understanding, become means by which they justify their position in the occupational field of LESLLA. It seems that this type of embodied capital, generally, is considered to have value in the LESLLA teaching field.

\section{Implications}

An implication of the study is the importance of recognising bilingual teachers' capital, not least in LESLLA teaching. Bilingual teachers offer an advantage to the learners, who are likely to benefit from a multilingual teaching approach. A suggestion is not just to actively involve bilingual teachers in LESLLA teaching, but to give them the opportunity to participate as initiated members of the school communities - regarded as capable and autonomous teachers, and to facilitate their acquisition of additional institutional capital essential in the field. Possibly, this will lead to a confident and stable professional teacher identity. Furthermore, the embodied capital of multi-linguistics and immigrant experiences that the bilingual teacher has should also be acknowledged in other types of education. This could help learners with immigrant experiences widen the horizon of the native learners, and challenge the view of 'native speaker teachers' as superior. 


\section{References}

Bourdieu, Pierre. 1990. The Logic of Practice. Translated by Richard Nice. Redwood City: Stanford University Press.

Bourdieu, Pierre. 1991. Language and Symbolic Power. Translated by Gino Raymond and Matthew Adamson. Cambridge: Polity Press.

Bourdieu, Pierre. 1996. “The Forms of Capital”. Translated by Richard Nice. In Education, Globalization \& Social Change, edited by Hugh. Lauder, Phillip. Brown, Jo-Anne. Dillabough, and A. H. Halsey, 105-118. Oxford: Oxford University Press.

Bourdieu, Pierre. 1998. Practical Reason: On the Theory of Action. Translated by Randal Johnson. Cambridge: Polity Press.

Braun, Virginia., and Victoria Clark. 2006. Using Thematic Analysis in Psychology. In Qualitative Research in Psychology, 3 (2): 77-101. doi: 10.1191/1478088706qp063oa

Cummins, Jim. 2015. How to Reverse a Legacy of Exclusion?: Identifying High-impact

Educational Responses. Language and Education, 29 (3): 272-279. doi: 10.1080/09500782.2014.994528

Ganuza, Natalia, and Christina Hedman. 2015. Struggles for Legitimacy in Mother Tongue Instruction in Sweden. Language and Education, 29 (2): 125-139. doi: 10.1080/09500782.2014.978871

Garcia, Ofelia. 2009. Bilingual Education in the 21st Century: A Global Perspective. Chichester: Wiley-Blackwell.

Ghanem, Carla. 2015. Teaching in the Foreign Language Classroom: How Being a Native or Non-native speaker of German Influences Culture Teaching. Language Teaching Research, 19 (2): 169-186. doi: 10.1177/1362168814541751

Handley, Karen, Andrew Sturdy, Robin Fincham, and Timothy Clark. 2006. Within and Beyond Communities of Practice: Making Sense of Learning Through Participation, Identity and Practice. Journal of Management Studies, 43 (3): 641-653.

Hodkinson, Heather, and Phil Hodkinson. 2004a. Rethinking the Concept of Community of Practice in Relation to schoolteachers' Workplace's Learning. International Journal of Training and Development, 8 (1): 21-31.

Hodkinson, Phil, and Heather Hodkinson. 2004b. The Significance of Individuals' Dispositions in Workplace Learning: A Case Study of Two Teachers. Journal of Education and Work, 17 (2): 167-182. doi:10.1080/13639080410001677383

Holliday, Adrian. 2006. Native-speakerism. ELT, 60 (4): 385-387. doi:10.1093/elt/ccl030

Kvale, Steinar, and Svend Brinkmann. (2009). Den kvalitativa forskningsintervjun. Lund: Studentlitteratur.

Lave, Jean, and Etienne Wenger. 1991. Situated Learning - Legitimate Peripheral Participation. Cambridge: Cambridge University Press.

Martin-Jones, Marilyn. 2017. "Bilingualism, Education and the Regulation of Access to Language Resources”. In Bilingualism: A Social Approach, edited by Monica. Heller, 161-182. Houndsmills, Basingstoke, Hampshire \& New York: Palgrave Macmillan.

McCarty, Teresa, James Collins, and Rodney Hopson. 2011. Dell Hymes and the New Language Policy Studies: Update from an Underdeveloped Country. Anthropology \& Education, 42 (4): 335-363. doi: 10.1111/j.1548-1492.2011.01143.x

Rubenstein Reich, Lena, and Annelis Jönsson. 2006. Invandrade lärares arbetssituation och läraridentitet - efter fyra år som lärare i den svenska skolan. Educare, 2, edited by Björn. Sundmark, 66-107. Malmö: Malmö University.

The Swedish Schools Inspectorate. 2010:7 Svenskundervisning för invandrare (sfi). En granskning av hur utbildningen formas efter deltagarnas förutsättningar och mål

The Swedish National Agency for Education. 1 July 2012. Kommunal Vuxenutbildning i Svenska för Invandrare: Kursplan och kommentarer. Retrieved from Läroplaner, 
ämnen \& kurser: www.skolverket.se/laroplaner-amnen-och-kurser/vuxenutbildning/sfi 16 October 2016

Thomas, Wayne and Virginia Collier. 1997. School Effectiveness for Language Minority Students. Washington: National Clearinghouse for Bilingual Education.

Valenta, Marko 2009. "Who Wants to Be a Travelling Teacher?" Bilingual Teachers and Weak Forms of Bilingual Education: The Norweigan Experience. European Journal of Teacher Education, 32 (1): 21-33. doi: 10.1080/02619760802509123

Wenger, Etienne. 1998. Communities of Practice: Learning, Meaning, and Identity. New York: Cambridge University Press.

Wenger-Trayner, Etienne, and Beverly Wenger-Trayner. 2015. “Theory”. In Learning in Landscapes of Practices, edited by Etienne Wenger-Trayner, Mark. Fenton O'Creevy, Steven. Hutchinson, Chris. Kubiak, and Beverly Wenger-Trayner, 13-29. Oxon: Routledge.

Vincent, Carol, and Simon Warren. 2001. "It Won't Take Long...": Interviewing, Ethics and Diversity. Qualitative Studies in Education, 14 (1): 39-53. 